\title{
Growth and yield of corn hybrids in response to association with Azospirillum brasilense and nitrogen fertilization ${ }^{1}$
}

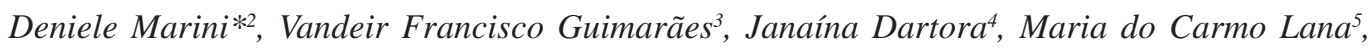 \\ Artur Soares Pinto Júnior ${ }^{6}$ \\ http://dx.doi.org/10.1590/0034-737X201562010015
}

\begin{abstract}
There is a growing interest in optimizing the positive effects of the association between Azospirillum bacteria and corn crop in order to reduce the use of nitrogen fertilizers. This study aimed to evaluate the inoculation efficiency of an A. brasilense-based commercial product in association with different rates of nitrogen fertilization in two corn genotypes. The experiment was arranged in a $2 \times 2 \times 5$ factorial randomized block design, with four replications. The treatments consisted of two corn hybrids (30F53 and CD386); with and without inoculation with a commercial product based on A. brasilense and five nitrogen rates $\left(0,40,80,120\right.$ and $\left.160 \mathrm{~kg} \mathrm{ha}^{-1}\right)$. The variables plant height, basal stem diameter, leaf area, shoot dry matter, leaf nitrogen content, length and diameter of the cob, weight of 100 grains and grain yield were evaluated. Inoculation with A. brasilense provided increases of 11 and $12 \%$ in leaf area and shoot dry matter, respectively. There were differences in the response of the corn hybrids for most variables and the increase in nitrogen supply provided increments in the growth and yield of corn.
\end{abstract}

Key words: Zea mays L., inoculation, nitrogen-fixing bacteria, plant hormones.

\section{RESUMO}

\section{Crescimento e produção de híbridos de milho em resposta à associação com Azospirillum brasilense e adubação nitrogenada}

Existe interesse em otimizar os efeitos positivos da associação entre bactérias do gênero Azospirillum e a cultura do milho, visando a reduzir o uso de fertilizantes nitrogenados. Neste trabalho, objetivou-se avaliar a eficiência da inoculação de produto comercial à base de $A$. brasilense, em associação com diferentes níveis de adubação nitrogenada, em dois genótipos de milho. O delineamento experimental empregado foi de blocos ao acaso, em esquema fatorial 2 x 2 x 5, com quatro repetições. Os tratamentos foram constituídos por dois híbridos de milho (30F53 e CD386); inoculação, ou não, de produto comercial à base de $A$. brasilense e cinco doses de nitrogênio $\left(0,40,80,120\right.$ e $\left.160 \mathrm{~kg} \mathrm{ha}^{-1}\right)$. Foram avaliadas as variáveis altura de planta, diâmetro basal do colmo, área foliar, matéria seca de parte aérea, teor de nitrogênio foliar, comprimento e diâmetro da espiga, massa de 100 grãos e produtividade de grãos. A inoculação com $A$. brasilense proporcionou incrementos de 11 e de $12 \%$, para área foliar e matéria seca de parte aérea do milho, respectivamente. Houve resposta diferenciada dos híbridos de milho para a maioria das variáveis analisadas e o incremento do fornecimento de nitrogênio proporcionou incrementos no desenvolvimento e na produtividade da cultura do milho.

Palavras-chave: Zea mays L., inoculação, bactérias diazotróficas, fito-hormônios.

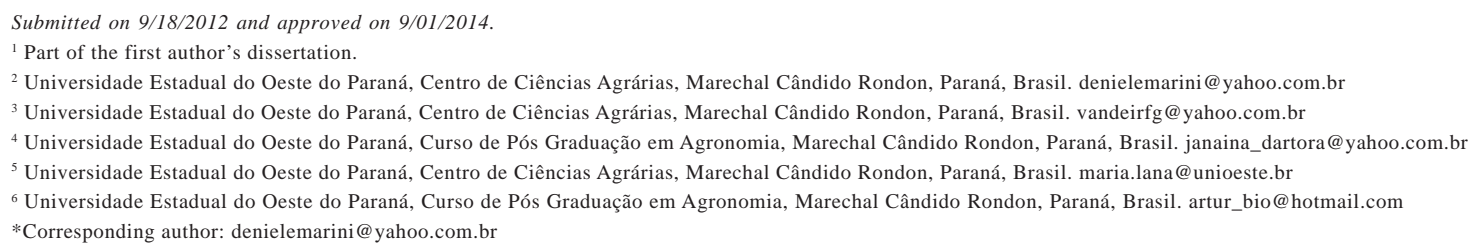




\section{INTRODUCTION}

The corn crop (Zea mays L.) has a great economic and social importance in Brazil, with the world's fourth largest grain production, of about 15.4 million hectares in the $2011 / 2012$ harvest and yield of $4,265 \mathrm{~kg} \mathrm{ha}^{-1}$ (CONAB, 2012).

Improvements in agronomic characteristics of corn genotypes and crop management practice have provided increases in yield and good financial results for producers.

The adequate supply of nutrients to plants is essential to achieve high yields, especially nitrogen $(\mathrm{N})$, since this element is one of the most limiting and required for corn production. Good management of nitrogen fertilization is essential for the corn crop (Fornasieri Filho, 1992). However, due to the high economic and environmental costs of the manufacturing process of nitrogen fixation for the production of nitrogen fertilizers, the agriculture faces the challenge of enhancing crop production and at the same time reducing the use of fertilizers to make the agricultural system more sustainable.

An alternative for the reduction of nitrogen fertilizer application in corn is the combination of the genetic potential of plants with inoculation of nitrogen fixing bacteria, such as those from the Azospirillum genus. Azospirillum bacteria are reported as promoting plant growth mainly because of the production of plant protection hormones (Okon \& Labandera-Gonzalez, 1994). Cavallet et al. (2000) found that inoculation with an Azospirillum spp-based commercial product increased corn grain yield in $17 \%$ on average. Reis Júnior et al. (2008) reported the effect of inoculation with A. amazonense on the accumulation of root dry matter, which was different for the corn genotypes evaluated.

Interactions between the plant genotype and the Azospirillum bacteria are one of the variables that contribute most to the complexity of responses to inoculation (Sala et al., 2005), determining the importance of the association of promising genotypes with nitrogen-fixing bacteria and nitrogen fertilization.

Therefore, this study aimed to evaluate the inoculation efficiency of an A. brasilense-based commercial product in association with different rates of nitrogen fertilization in two corn genotypes.

\section{MATERIALS AND METHODS}

The experiment was conducted in the summer season of the 2010/2011 harvest by direct seeding in the municipality of Marechal Cândido Rondon - PR (54 22' O; $24^{\circ} 46^{\prime} \mathrm{S}, 420 \mathrm{~m}$ altitude). The climate, in the Koppen system, is subtropical humid mesothermal (Cfa). Data of rainfall and minimum, maximum and monthly average temperatures during the experiment are shown in Figure 1.

The soil was classified as clayey Oxisol (LVef), with the following chemical characteristics $(0-20 \mathrm{~cm}): \mathrm{pH}$ in $\mathrm{CaCl}_{2}=5.50 ; \mathrm{M} . \mathrm{O} .=34.17 \mathrm{~g} \mathrm{dm}^{-3} ; \mathrm{P}=18.34 \mathrm{mg} \mathrm{dm}^{-3} ; \mathrm{K} . \mathrm{Ca}$ and $\mathrm{Mg} .0 .20 ; 2.92$ and $1.52 \mathrm{cmol}_{\mathrm{c}} \mathrm{dm}^{-3}$, respectively; $\mathrm{H}+\mathrm{Al}=7.19 \mathrm{cmol}_{\mathrm{c}} \mathrm{dm}^{-3} ; \mathrm{Cu}=7.26 \mathrm{mg} \mathrm{dm}^{-3} ; \mathrm{Mn}=134.00 \mathrm{mg}$ $\mathrm{dm}^{-3} ; \mathrm{Fe}=37.96 \mathrm{mg} \mathrm{dm}^{-3} ; \mathrm{Zn}=1.50 \mathrm{mg} \mathrm{dm}^{-3} ; \mathrm{SB}=4.64 \mathrm{cmol}_{\mathrm{c}}$ $\mathrm{dm}^{-3} ; \mathrm{CTC}=11.84 \mathrm{cmol}_{\mathrm{c}} \mathrm{dm}^{-3} ; \mathrm{Al}=5.81 \%$ and $\mathrm{V}=49.5 \%$.

The experiment was arranged in a $2 \times 2 \times 5$ factorial randomized block design, with four replications. The first factor consisted of the corn hybrids 30F53 and CD386, both simple hybrids and early-maturing; the second factor was the inoculation or not of a liquid $A$. brasilense-based commercial product and the third factor was the $\mathrm{N}$ rates 0 , $40,80,120$ and $160 \mathrm{~kg} \mathrm{ha}^{-1}$ of $\mathrm{N}$.

Each plot consisted of six $5 \mathrm{~m}$-long rows and $0.7 \mathrm{~m}$ spacing between rows. The harvest area was the two central rows, discarding $1.0 \mathrm{~m}$ border on each end.

Corn seeds were inoculated with a commercial product based on the Ab-V5 and Ab-V6 strains of $A$. brasilense $\left(2 \times 10^{8} \mathrm{CFU} \mathrm{\textrm {mL } ^ { - 1 }}\right)$ in the proportion of 100 $\mathrm{mL}$ of the product to 60,000 seeds. The inoculation was performed by adding the inoculant with an automatic pipette directly on the seeds, which were shaken in plastic bags for uniform product distribution. The sowing was carried out about an hour after inoculation.

At planting, the starter fertilization was applied using the rates $40 \mathrm{~kg} \mathrm{ha}^{-1}$ of $\mathrm{P}_{2} \mathrm{O}_{5}, 50 \mathrm{~kg} \mathrm{ha}^{-1}$ of $\mathrm{K}_{2} \mathrm{O}$ and $30 \mathrm{~kg}^{-}$ ${ }^{1}$ of $\mathrm{N}$, without the nitrogen fertilization for the treatments without $\mathrm{N}$. The remaining $\mathrm{N}$ rate was sidedressed, according to the treatments, between the V4 and V6 stages, using urea $(46 \% \mathrm{~N})$ as $\mathrm{N}$ source.

Corn seeds were sowed with a manual seed planter, two seeds per hole, on 08/10/10, yielding five plants per meter after thinning. During the experiment, a mixture of selective herbicides for use in corn (triazine - 5.0 $\mathrm{L} \mathrm{ha}^{-1}$ and nicosulfuron - 1, $5 \mathrm{~L} \mathrm{ha}^{-1}$ ) was applied 14 days after sowing (DAS) and two pesticide applications, with thiamethoxam + lambda-cyhalothrin as active ingredients $\left(0.25 \mathrm{~L} \mathrm{~h}^{-1}\right)$, at 18 and $30 \mathrm{DAS}$.

At the flowering stage, leaf samples were taken from corn plants to determine the $\mathrm{N}$ content in the leaves. The middle third section of the opposite leaf and below the point of insertion of the main ear was collected from a total of ten leaves per experimental unit, according to the methodology proposed by Tedesco et al. (1995) to determine $\mathrm{N}$ contents.

Plants were randomly collected at the reproductive stage (R3) for biometric evaluation. Still in the field, the plants were evaluated for height and basal stem diameter, with a ruler and a digital caliper, respectively. The harvested plants were taken to the laboratory, separated 
into different parts and placed in a forced air oven at 65 ${ }^{\circ} \mathrm{C} \pm 2{ }^{\circ} \mathrm{C}$ for $72 \mathrm{~h}$ to determine shoot dry matter. Leaf area was measured using the sampling method proposed by Benincasa (2003).

After manual harvesting of the harvest area, the ears were shelled to determine yield, based on the grain production of the harvest area, after grain moisture correction to $13 \%$ (wet basis). Ten representative ears were sampled per plot to determine the production components ear length, ear diameter and 100 seed weight.

Data were subjected to analysis of variance, using the SISVAR software (Ferreira, 2008), and means were compared by the Tukey test ( $\mathrm{p} \leq 0.05$ ). Regression analysis was used for the responses of the different variables to the $\mathrm{N}$ rates.

\section{RESULTS AND DISCUSSION}

The interaction among hybrids, inoculation and $\mathrm{N}$ rates was not significant for any variable. There was interaction only between hybrids and $\mathrm{N}$ rates for yield.

The hybrid 30F53 was superior to hybrid CD386 for plant height, leaf area, ear length and grain yield, indicating its greater yield potential (Tables 1 and 2). CD386 had greater basal stem diameter, leaf $\mathrm{N}$ content, ear diameter and 100 seed weight than 30F53 (Tables 1 and 2). Dotto et al. (2010), in a study with $H$. seropedicae inoculation and $\mathrm{N}$ rates, also found different performances of corn genotypes for the traits evaluated.

No effects were found after inoculation with $A$. brasilense on plant height (Table 1), which can be attributed to the high heritability of this trait. Campos et al. (2000) and Cavallet et al. (2000) worked with the
Azospirillum-based inoculant "Graminante" in corn and also found no effect of inoculation on plant height.

There was response of plant height to nitrogen fertilization, with quadratic polynomial fit, as a function of the different rates (Figure 2A), with maximum plant height $(224 \mathrm{~cm})$ at the rate of $112.5 \mathrm{~kg} \mathrm{ha}^{-1} \mathrm{~N}$. The lower height of plants subjected to lower $\mathrm{N}$ doses is associated with the delayed cell division in the growing points (Arnon, 1975). Sá (1996) evaluated the combination of $\mathrm{N}$ rates in corn at sowing and sidedress and found reduced plant growth and leaf yellowing in the absence of nitrogen fertilization, as it was also observed in this study.

There was no effect of inoculation on basal stem diameter, corroborating the results obtained by Dotto et al. (2010). However, an increasing linear adjustment of basal stem diameter was observed as a function of $\mathrm{N}$ rates (Figure 2B), with increase of $0.0126 \mathrm{~mm}$ for each $\mathrm{kg}$ of $\mathrm{N}$ added to the soil. It is noteworthy that a greater stem diameter is directly related to increased production, since this structure is involved in the storage of soluble solids, which may subsequently be used in the formation of seeds (Fancelli \& Dourado Neto, 2000).

The inoculation with $A$. brasilense influenced the leaf area and shoot dry matter, with increases of 11 and $12 \%$ respectively for these variables in relation to the treatment without inoculation (Table 1). Quadros (2009) evaluated the agronomic performance of corn hybrids inoculated with Azospirillum in association with nitrogen fertilization and found even greater increases, up to $53 \%$, in shoot dry matter yield for the inoculant treatment in relation to the control, showing the beneficial effect of inoculation.

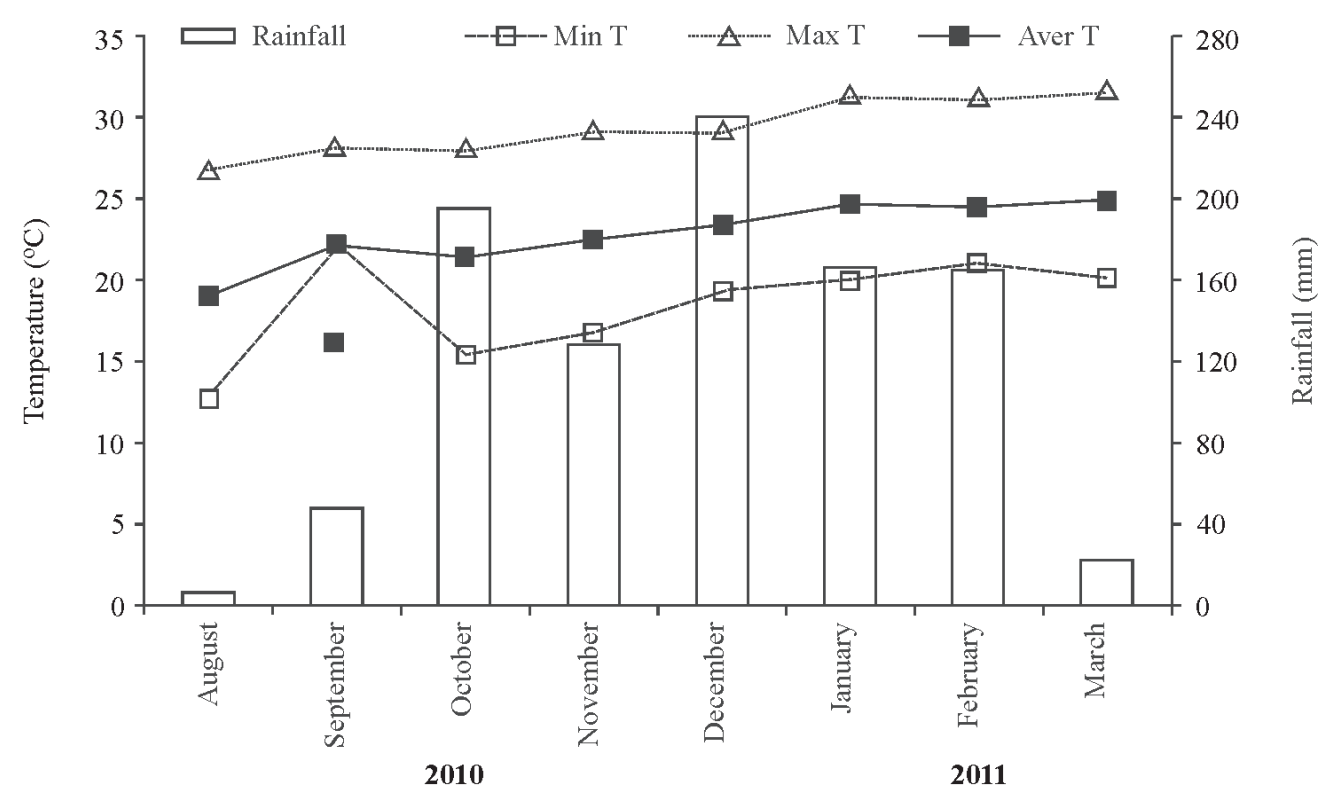

Figure 1. Rainfall accumulated and minimum, maximum and monthly average temperature from August/2010 to March/2011 in the municipality of Marechal Candido Rondon, PR. 
Increases in shoot dry matter and leaf area in response to inoculation with $A$. brasilense are related to the growth promoting effect of Azospirillum, because of the production of plant hormones such as auxins, gibberellins and indole acetic acid (IAA) (Bashan \& Holguin, 1997). According to Okon \& Labandera-Gonzalez (1994), these micro-organisms, through the production of phytohormones, stimulate the density and length of root hairs as well as the rate of appearance of lateral roots, resulting in increased root contact surface, which enhances the recovery and utilization of water and nutrients available in the soil (Baldani et al., 1997).

There was increasing linear fit for leaf area of plants as the $\mathrm{N}$ rate increases (Figure 2C), with of $0.171 \mathrm{dm}^{2}$ increase for each $\mathrm{kg}$ of $\mathrm{N}$ added. Nitrogen is directly related to plant growth and essential substances for plant development, such as proteins, enzymes, co-enzymes, nucleic acids, phytochrome, photosynthetic pigments, etc. (Bull, 1993). Furthermore, $\mathrm{N}$ favors the growth of roots, providing the plant with conditions for enhanced uptake of water and nutrients (Rao et al., 1992).

The leaf nitrogen content was not influenced by inoculation (Table 1), confirming the results of Dotto et al. (2010). Because of the nitrogen fertilization, there was a quadratic polynomial fit for leaf $\mathrm{N}$ content (Figure 2D), with a maximum $\mathrm{N}$ leaf (40.41 $\mathrm{g} \mathrm{kg}^{-1}$ ) obtained with the rate of $87.4 \mathrm{~kg} \mathrm{ha}^{-1} \mathrm{~N}$. The leaf nitrogen contents found in this study were above the sufficiency range considered as suitable for corn (27.5 to $32.5 \mathrm{~g} \mathrm{~kg}^{-1}$ of N) by Malavolta et al. (1997), however, toxicity symptoms were not observed in corn plants during the experiment.

There was no effect of inoculation of A. brasilense on yield components (Table 2). However, although without statistical difference, it is observed that with inoculation, grain yield achieved $7967.01 \mathrm{~kg} \mathrm{ha}^{-1}$, indicating that the inoculum provided an increase of 259 $\mathrm{kg}$, four more bags per hectare than the control treatment (7707.33 $\left.\mathrm{kg} \mathrm{ha}^{-1}\right)$, suggesting its application in corn cultivation.

Besides the production of growth-promoting substances, the positive response of plants to inoculation with nitrogen-fixing bacteria can be due to other factors, such as protection against pathogens, increased stress resistance (Huergo et al., 2008), the phosphate solubilization and the biological nitrogen fixation itself (Gray \& Smith, 2005). Nevertheless, despite the advantages of providing nitrogen-fixing bacteria to the plants, their efficiency may be compromised for being associated freely with the plant and therefore more vulnerable to the environment (Gyaneshwar et al., 2002), because, unlike the

Table 1. Plant height $(\mathrm{cm})$, basal stem diameter $(\mathrm{mm})$, leaf area $\left(\mathrm{dm}^{2}\right)$, shoot dry matter $\left(\mathrm{kg} \mathrm{ha}^{-1}\right)$ and leaf nitrogen content $\left(\mathrm{g} \mathrm{kg}^{-1}\right)$ of corn plants as a function of hybrid and inoculation with $A$. brasilense.

\begin{tabular}{|c|c|c|c|c|c|}
\hline Sources of variation & $\begin{array}{l}\text { Plant height } \\
\text { (cm) }\end{array}$ & $\begin{array}{l}\text { Stem diameter } \\
(\mathbf{m m})\end{array}$ & $\begin{array}{l}\text { Leaf area } \\
\qquad\left(\mathbf{d m}^{2}\right)\end{array}$ & $\begin{array}{l}\text { Shoot dry matter } \\
\qquad\left(\mathrm{kg} \mathrm{ha}^{-1}\right)\end{array}$ & $\begin{array}{l}\text { Leaf N } \\
\left(\mathrm{g} \mathrm{kg}^{-1}\right)\end{array}$ \\
\hline \multicolumn{6}{|l|}{ HYBRID } \\
\hline $30 \mathrm{~F} 53$ & $231 \mathrm{a}$ & $24.7 \mathrm{~b}$ & $105.6 \mathrm{a}$ & $597.1 \mathrm{a}$ & $37.2 \mathrm{~b}$ \\
\hline CD386 & $213 b$ & $25.8 \mathrm{a}$ & $87.3 \mathrm{~b}$ & $659.4 \mathrm{a}$ & $39.7 \mathrm{a}$ \\
\hline \multicolumn{6}{|l|}{ INOCULATION } \\
\hline Control & $223 \mathrm{a}$ & $25.6 \mathrm{a}$ & $91.3 \mathrm{~b}$ & $591.8 \mathrm{~b}$ & $38.2 \mathrm{a}$ \\
\hline A. brasilense & $221 \mathrm{a}$ & $25.0 \mathrm{a}$ & $101.6 \mathrm{a}$ & $664.7 \mathrm{a}$ & $38.7 \mathrm{a}$ \\
\hline C.V. $(\%)$ & 3.65 & 7.29 & 22.80 & 23.05 & 10.33 \\
\hline
\end{tabular}

Means followed by the same letter in the column are not significantly different by the $\mathrm{F}$ test at $\mathrm{p} \leq 0.05$.

Table 2. Ear length $(\mathrm{cm})$, ear diameter $(\mathrm{mm}), 100$ seed weight $(\mathrm{g})$ and grain yield $\left(\mathrm{kg} \mathrm{ha}^{-1}\right)$ of corn as a function of the hybrid and inoculation with $A$. brasilense.

\begin{tabular}{lcccc}
\hline Sources of variation & $\begin{array}{c}\text { Ear length } \\
(\mathbf{c m})\end{array}$ & $\begin{array}{c}\text { Ear diameter } \\
(\mathbf{m m})\end{array}$ & $\begin{array}{c}\mathbf{1 0 0} \text { seed weight } \\
(\mathbf{g})\end{array}$ & $\begin{array}{c}\text { Yield } \\
\left(\mathbf{k g ~ h a}^{-1}\right)\end{array}$ \\
\hline HYBRID & $18.35 \mathrm{a}$ & $52.16 \mathrm{~b}$ & $35.97 \mathrm{~b}$ & $9008.13 \mathrm{a}$ \\
30 F53 & $16.59 \mathrm{~b}$ & $55.07 \mathrm{a}$ & $40.64 \mathrm{a}$ & $6666.21 \mathrm{~b}$ \\
CD386 & $17.43 \mathrm{a}$ & & & $7707.33 \mathrm{a}$ \\
\hline INOCULATION & $17.52 \mathrm{a}$ & $53.60 \mathrm{a}$ & $38.42 \mathrm{a}$ & $7967.01 \mathrm{a}$ \\
Control & 5.36 & $53.63 \mathrm{a}$ & $38.20 \mathrm{a}$ & 12.20 \\
A. brasilense & 2.04 & 5.75 & \\
\hline C.V. $(\%)$ &
\end{tabular}

Means followed by the same letter in the column are not significantly different by the $\mathrm{F}$ test at $\mathrm{p} \leq 0.05$.

Rev. Ceres, Viçosa, v. 62, n.1, p. 117-123, jan/fev, 2015 
symbiotic interaction between rhizobium and legumes in which nodules are formed, no macroscopic structure has been described in the association nitrogen fixing bacteria-grasses (Lopes, 2007).

Although it was not possible to associate the inoculation of $A$. brasilense with the $\mathrm{N}$ rates in this study, positive effects of this association are frequently reported in the literature. Machado et al. (1998) tested 10 and $100 \mathrm{~kg} \mathrm{ha}^{-1}$ of $\mathrm{N}$ associated with inoculation with a mixture of nitrogen-fixing bacteria and reported increase in the production from $4830 \mathrm{~kg} \mathrm{ha}^{-1}$ to $5790 \mathrm{~kg}$ $\mathrm{ha}^{-1}$, depending on the inoculum, for the rate of $100 \mathrm{~kg}$ $\mathrm{ha}^{-1}$ N. Dobbelaere et al. (2002) found that the positive effect of inoculation with A. brasilense, strain Sp 245, and $A$. irakense, strain $\mathrm{KBC} 1$, was greater when associated with N. Quadros (2009) reported that the addition of $50 \mathrm{~kg} \mathrm{ha}^{-1}$ of $\mathrm{N}$ in association with $A$. brasilense gave a performance for grain yield equivalent to the application of $130 \mathrm{~kg} \mathrm{ha}^{-1} \mathrm{~N}$.

However, inoculation with Azospirillum spp not always give positive responses, which has been attributed mainly to the host plant genotype (Iniguez et al., 2004) and soil characteristics (Dobbelaere et al., 2002), confirming the importance of selecting strains suitable for the growing conditions and cultivars used in each region (Cavallet et al., 2000).
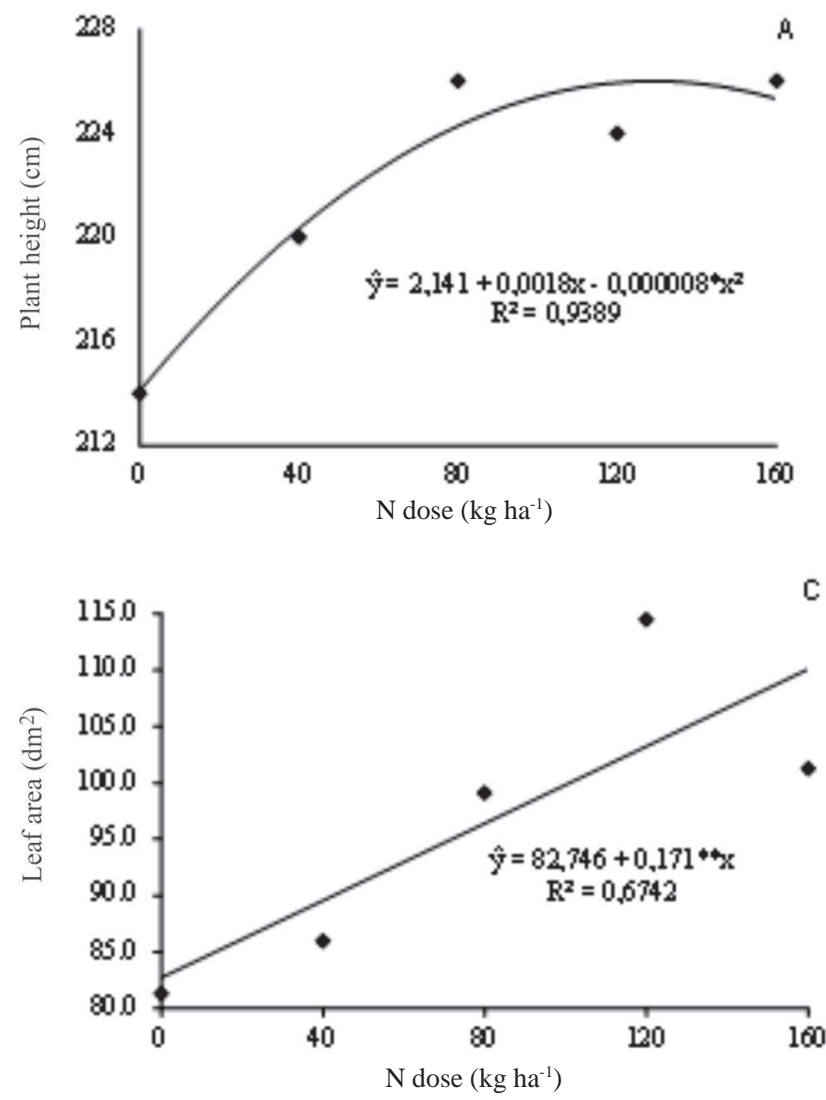

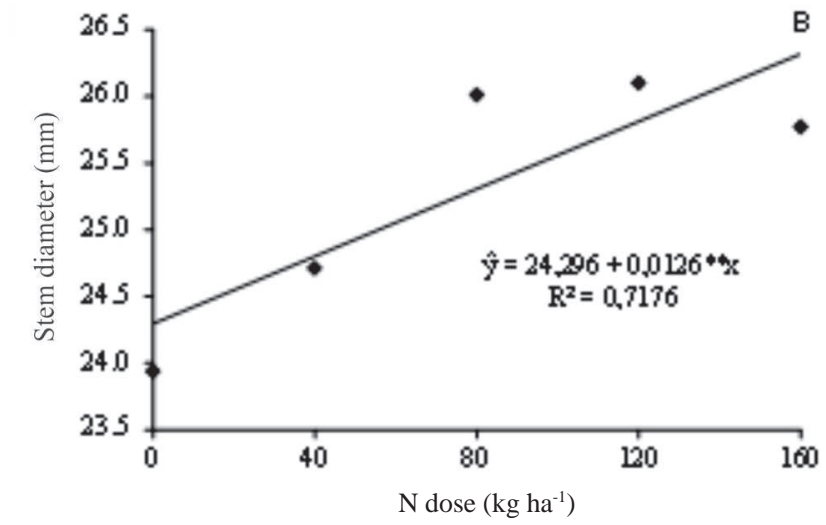

The ear length fit to a quadratic polynomial model, as a function of the $\mathrm{N}$ rates (Figure $3 \mathrm{~A}$ ), with maximum length $(18.1 \mathrm{~cm})$ at the rate $150 \mathrm{~kg} \mathrm{ha}^{-1} \mathrm{~N}$.

There was increasing linear fit for ear diameter and 100 seed weight as a function of $\mathrm{N}$ rates (Figures 3B and $3 \mathrm{C}$ ), with increase of $0.018 \mathrm{~mm}$ in ear diameter and $0.025 \mathrm{~g}$ in 100 seed weight for each $\mathrm{kg}$ of $\mathrm{N}$ added. According to Fancelli \& Dourado Neto (2000), the seed weight is an important grain yield component, since the occurrence of any kind of stress, biotic or abiotic, after flowering, can affect it significantly.

The interaction between hybrid and $\mathrm{N}$ rates was significant for yield. Figure 3D shows a cubic model fit for hybrid 30F53, with high grain yield at $160 \mathrm{~kg} \mathrm{ha}^{-1}$ of $\mathrm{N}$. There was increasing linear fit for yield of hybrid CD386 as a function of the $\mathrm{N}$ rate, with increase of $14.6 \mathrm{~kg} \mathrm{ha}^{-1}$ crop yield for each $\mathrm{kg}$ of $\mathrm{N}$ added to the soil.

The significant interaction between genotype $\mathrm{x} \mathrm{N}$ rates was also reported by Ferreira et al. (2009), who found that increasing $\mathrm{N}$ rates led to a direct impact on grain yield of three corn genotypes. The increase in yield provided by $\mathrm{N}$ can be attributed to the effect of the nutrient on cell division and expansion, providing increased photosynthetically active plant leaf area (Büll, 1993) and, consequently, dry matter production. Thus, photosynthate translocation to grain is enhanced,

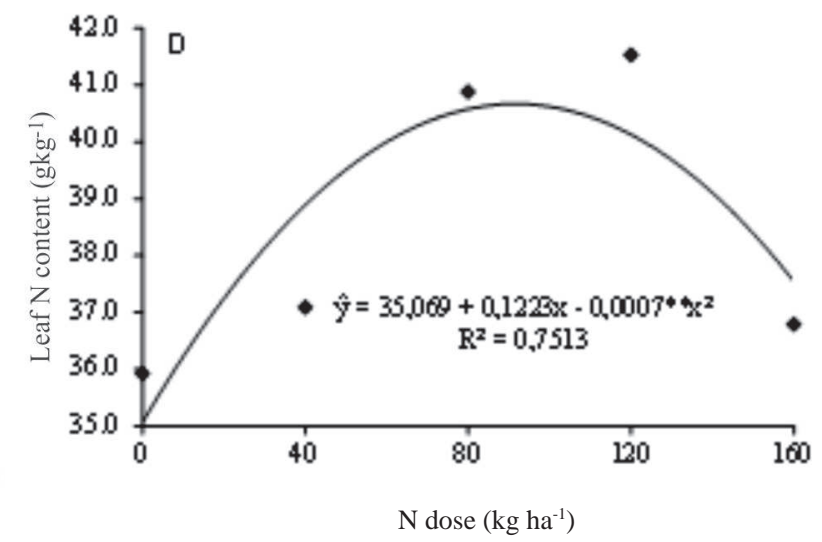

Figure 2. Height (A), basal stem diameter (B), leaf area (C) and leaf nitrogen content (D) of corn plants as a function of the application of different $\mathrm{N}$ rates. 

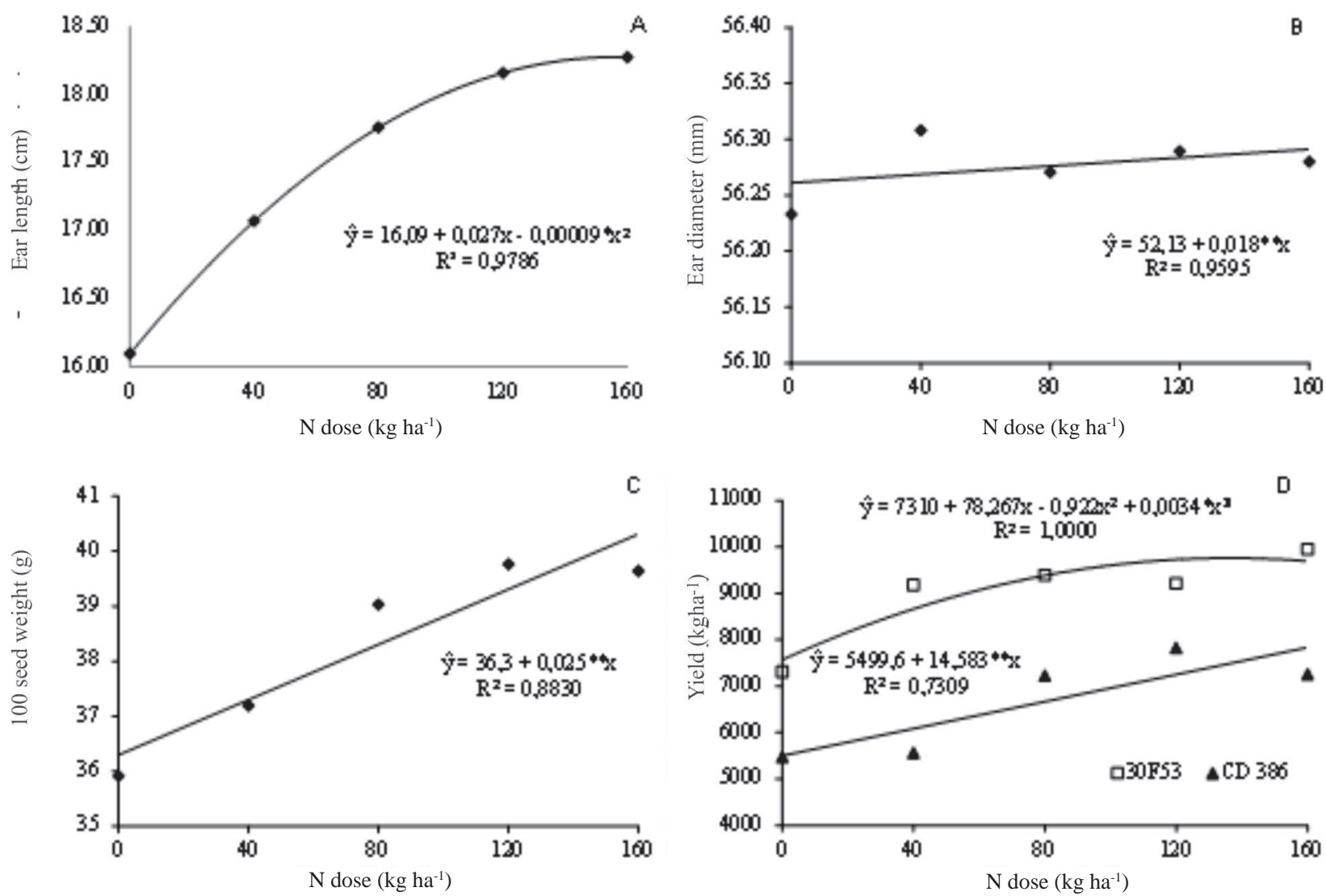

Figure 3. Ear length (A), ear diameter (B), 100 seed weight (C) and yield (D) as a function of different nitrogen rates.

resulting in increased grain yield (Escosteguy et al., 1997).

Considering that plant genotype is a key factor to benefit from plant-bacteria interaction and the great influence of the environment on the survival and activity of nitrogen-fixing bacteria, further studies are needed in order to combine inoculation of Azospirillum spp. with promising genotypes in different corn growing regions.

\section{CONCLUSIONS}

The hybrid 30F53 showed higher yield potential than CD386, in the conditions of this study.

Inoculation with $A$. brasilense provided increases in leaf area and shoot dry matter of the hybrids.

In general, the higher $\mathrm{N}$ supply resulted in increase in growth and grain yield of corn plants.

\section{ACKNOWLEDGEMENTS}

The authors want to thank the Araucaria Foundation of Scientific Support and Technological Development of Paraná affiliated to the State Secretariat of Science, Technology and Higher Education - SETI; CAPES / PNPD, and CNPq / INCT for the financial support.

\section{REFERENCES}

Arnon I (1975) Mineral nutrition of maize. Bern, International Potash Institute. $452 \mathrm{p}$.

Baldani JI, Caruso L, Baldani VLD, Goi SR \& Dobereiner J (1997) Recent advances in BNF with non-legume plants. Soil Biology and Biochemistry, 29:911-922.

Bashan Y \& Holguin G (1997) Azospirillum - plant relationships: environmental and physiological advances (1990-1996). Canadian Journal of Microbiology, 43:103-121.

Benincasa MMP (2003) Análise de Crescimento de Plantas: Noções Básicas. $2^{\mathrm{a} e d . ~ J a b o t i c a b a l, ~ F U N E P . ~ 42 p . ~}$

Büll LT (1993) Nutrição mineral do milho. In: Bull LT \& Cantarella H (Eds.) Cultura do milho: fatores que afetam a produtividade. Piracicaba, Potafos. p.63-131.

Campos BHC, Theisen S \& Gnatta V (2000) Avaliação do inoculante "Graminante" na cultura do milho. Ciência Rural, 30:713-715.

Cavallet LE, Pessoa ACS dos, Helmich JJ, Helmich PR \& Ost CF (2000) Produtividade do milho em resposta à aplicação de nitrogênio e inoculação das sementes com Azospirillum spp. Revista Brasileira de Engenharia Agrícola e Ambiental, 4:129-132.

CONAB - Companhia Nacional de Abastecimento (2012) Acompanhamento da Safra Brasileira de Grãos 2011/12 - $8^{\circ}$ levantamento. Disponível em: <http//www.conab.gov.br>. Acessado em: 20 de maio de 2012.

Dobbelaere S, Croonenborghs A, Thys A, Ptacek D, Okon Y \& Vanderleyden J (2002) Effect of inoculation with wild type Azospirillum brasilense and A. irakense strains on development and nitrogen uptake of spring wheat and grain maize. Biology and Fertility of Soils, 36:284-297. 
Dotto AP, Lana M do C, Steiner F \& Frandoloso JF (2010) Produtividade do milho em resposta à inoculação com Herbaspirillum seropedicae sob diferentes níveis de nitrogênio. Revista Brasileira de Ciências Agrárias, 5:376-382.

Escosteguy PAV, Rizzardi MA \& Argenta G (1997) Doses e épocas de aplicação de nitrogênio em cobertura na cultura do milho em duas épocas de semeadura. Revista Brasileira de Ciência do Solo, 21:7177.

Fancelli AL \& Dourado-Neto D (2000) Produção de milho. Guaíba, Agropecuária. 360p.

Ferreira DF (2008) SISVAR: um programa para análises e ensino de estatística. Revista Symposium, 6:36-41.

Ferreira A de O, Sá JC de M, Briedis C \& Figueiredo AG de (2009) Desempenho de genótipos de milho cultivados com diferentes quantidades de palha de aveia-preta e doses de nitrogênio. Pesquisa Agropecuária Brasileira, 44:173-179.

Fornasieri Filho D (1992) A cultura do milho. Jaboticabal, FUNEP $273 \mathrm{p}$.

Gray EJ \& Smith DL (2005) Intracellular and extracellular PGPR commonalities and distinctions in the plant-bacterium signaling processes. Soil Biology and Biochemistry, 37:395-412.

Gyaneshwar P, Kumar GN, Parekh LJ \& Poole PS (2002) Role of soil microorganisms in improving $\mathrm{P}$ nutrition of plants. Plant Soil, 245:83-93.

Huergo LF, Monteiro RA, Bonatto AC, Rigo LU, Steffens MBR, Cruz LM, Chubatsu LS, Souza EM \& Pedrosa FO (2008) Regulation of nitrogen fixation in Azospirillum brasilense. In: Cassán FD \& Salomone IG de (Eds.) Azospirillum sp.: cell physiology, plant interactions and agronomic research in Argentina. Córdoba, Asociación Argentina de Microbiología. p.17-28.

Iniguez AL, Dong Y \& Triplett EW (2004) Nitrogen fixation in whea provided by Klebsiella pneumonia 342. Molecular Plant-Microbe Interactions, 17:1078-1085.
Lopes ES (2007) Fixação biológica do nitrogênio no sistema solo-planta. In: Yamada T, Stipp e Abdalla SR \& Vitti GC (Eds.) Nitrogênio e enxofre na agricultura brasileira. Piracicaba, IPNI Brasil. p.43-72.

Machado AT, Sodek L, Döbereiner J \& Reis VM (1998) Efeito da adubação nitrogenada e da inoculação com bactérias diazotróficas no comportamento bioquímico da cultivar de milho Nitroflint. Pesquisa Agropecuária Brasileira, 33:961-970.

Malavolta E, Vitti GC \& Oliveira SA de (1997) Avaliação do estado nutricional das plantas: princípios e aplicações. $2^{\mathrm{a}}$ ed. Piracicaba, Potafos. 319p.

Okon Y \& Labandera-Gonzalez C (1994) Agronomic application of Azospirillum: an evaluation of 20 years worldwide field incubation. Soil Biology and Biochemistry, 26:1591-1601.

Quadros PD de (2009) Inoculação de Azospirillum spp. em sementes de genótipos de milho cultivados no Rio Grande do Sul. Dissertação Mestrado. Universidade Federal do Rio Grande do Sul, Porto Alegre. $62 \mathrm{p}$.

Rao ACS, Smith JL, Parr JF \& Papendick RI (1992) Considerations in estimating nitrogen recovery efficiency by the difference and isotopic dilution methods. Fertilizer Research, 33:209-217.

Reis Júnior FB, Machado CTT, Machado AT \& Sodek L (2008) Inoculação de Azospirillum amazonense em dois genótipos de milho sob diferentes regimes de nitrogênio. Revista Brasileira de Ciência do Solo, 32:1139-1146.

Sá JCM (1996) Manejo de nitrogênio na cultura de milho no sistema de plantio direto. Passo Fundo, Aldeia Norte. 23p.

Sala VMR, Freitas S dos S, Donzeli VP, Freitas JG, Gallo PB \& Silveira APD da (2005) Ocorrência e efeito de bactérias diazotróficas em genótipos de trigo. Revista Brasileira de Ciência do Solo, 29:345-352.

Tedesco MJ, Gianello C, Bissani CA, Bohnen H \& Volkweiss SJ (1995) Análises de solo, planta e outros materiais. Porto Alegre, UFRGS. 175p. (Boletim técnico, 5). 